\title{
Article \\ Contribution to the Understanding of the Interaction between a Polydopamine Molecular Imprint and a Protein Model: Ionic Strength and pH Effect Investigation
}

\author{
Amal Tlili 1,2®, Ghada Attia ${ }^{2}$, Sohayb Khaoulani ${ }^{2}$, Zouhour Mazouz ${ }^{3}$, Chouki Zerrouki ${ }^{2}{ }^{\circledR}$, Nourdin Yaakoubi ${ }^{4}$, \\ Ali Othmane ${ }^{1, *}$ and Najla Fourati ${ }^{2, *}$ (D) \\ 1 LIMA Laboratory, Faculty of Medicine of Monastir, Monastir University, Av. Avicenne, \\ Monastir 5019, Tunisia; amaltlili24@gmail.com \\ 2 SATIE Laboratory, Cnam, UMR CNRS 8029, 292 Rue Saint Martin, 75003 Paris, France; \\ ghada.attia@lecnam.net (G.A.); sohayb.khaoulani@lecnam.net (S.K.); zerrouki@cnam.fr (C.Z.) \\ 3 NANOMISENE Laboratory, CRMN, Technopôle Sousse, Sousse University, Sousse 4050, Tunisia; \\ mazouz.zouhour645@gmail.com \\ 4 LAUM Laboratory, Le Mans University, UMR CNR 6613, Avenue Olivier Messiaen, CEDEX 9, \\ 72085 Le Mans, France; Nourdin.Yaakoubi@univ-lemans.fr \\ * Correspondence: ali.othmane54@gmail.com (A.O.); fourati@cnam.fr (N.F.)
}

\section{check for}

updates

Citation: Tlili, A.; Attia, G.; Khaoulani, S.; Mazouz, Z.; Zerrouki, C.; Yaakoubi, N.; Othmane, A.; Fourati, N. Contribution to the Understanding of the Interaction between a Polydopamine Molecular Imprint and a Protein Model: Ionic Strength and $\mathrm{pH}$ Effect Investigation. Sensors 2021, 21, 619. https:// doi.org/10.3390/s21020619

Received: 18 December 2020 Accepted: 15 January 2021 Published: 17 January 2021

Publisher's Note: MDPI stays neutral with regard to jurisdictional clai$\mathrm{ms}$ in published maps and institutional affiliations.

Copyright: () 2021 by the authors. Licensee MDPI, Basel, Switzerland. This article is an open access article distributed under the terms and conditions of the Creative Commons Attribution (CC BY) license (https:// creativecommons.org/licenses/by/ $4.0 /)$.

\begin{abstract}
Several studies were devoted to the design of molecularly imprinted polymer (MIP)-based sensors for the detection of a given protein. Here, we bring elements that could contribute to the understanding of the interaction mechanism involved in the recognition of a protein by an imprint. For this purpose, a polydopamine (PDA)-MIP was designed for bovine serum albumin (BSA) recognition. Prior to BSA grafting, the gold surfaces were functionalized with mixed self-assembled monolayers of (MUDA)/(MHOH) $(1 / 9, v / v)$. The MIP was then elaborated by dopamine electropolymerization and further extraction of BSA templates by incubating the electrode in proteinase K solution. Three complementary techniques, electrochemistry, zetametry, and Fourier-transform infrared spectrometry, were used to investigate $\mathrm{pH}$ and ionic strength effects on a MIP's design and the further recognition process of the analytes by the imprints. Several MIPs were thus designed in acidic, neutral, and basic media and at various ionic strength values. Results indicate that the most appropriate conditions, to achieve a successful MIPs, were an ionic strength of $167 \mathrm{mM}$ and a $\mathrm{pH}$ of 7.4. Sensitivity and dissociation constant of the designed sensor were of order of $(3.36 \pm 0.13) \mu \mathrm{A} \cdot \mathrm{cm}^{-2} \cdot \mathrm{mg}^{-1} \cdot \mathrm{mL}$ and $(8.56 \pm 6.09) \times 10^{-11} \mathrm{mg} / \mathrm{mL}$, respectively.
\end{abstract}

Keywords: molecularly imprinted polymer; bovine serum albumin; ionic strength; $\mathrm{pH}$; dissociation constant

\section{Introduction}

Molecularly imprinted polymers (MIPs) have received widespread attention in bioanalytical methods such as solid phase extraction (SPE) [1], catalytic processes [2], and chromatography techniques [3]. MIPs are increasingly investigated due to their numerous advantages: high affinity towards analytes of interest; chemical, physical, and thermal stability; and straightforward preparation [4]. The rational design of molecular imprinting consists in generating synthetic receptors mimicking natural recognition elements [5]. Concretely a polymeric matrix is first achieved around the molecules of interest. Various types of interactions can be involved, between the functional monomers, the analyte, and the cross linker, during this process, e.g., electrostatic forces, $\pi-\pi$ interactions, hydrogen bondings, Van Der Waals forces, and hydrophobicity $[6,7]$. The further extraction of templates permits to release accessible sites for the analyte rebinding [8]. The recognition process is consequently controlled by the orientation, arrangements, and the nature of functional groups within these binding sites [5,9]. 
The success of small molecules imprinting has motivated the researchers to investigate more complex templates, such as viruses [10], peptides [11], and especially proteins [12]. Nevertheless, proteins' molecular imprinting is complex because of: (i) the large size of these entities, which makes possible their deep tapering in the polymeric matrix and rends thus difficult templates release [13]; (ii) proteins dependence on osmolarity, ionic strength, and $\mathrm{pH}$, three parameters, which can alter both their stability and their solubility [13]; and (iii) the possibility of protein's conformation change during the polymerization process [14].

In a previous work, Bereli et al., have designed lysozyme (Lyz)-imprinted supermacroporous cryogels to purify Lyz protein from egg's white [15]. The authors have explored the effects of external stimuli, such as salt concentration $(\mathrm{NaCl})$, on the lysozyme adsorption. Their results indicate that the augmentation of $\mathrm{NaCl}$ concentration leads to a decrease in Lyz adsorption capacity from 16.6 to $6.7 \mathrm{mg} / \mathrm{g}$. This was attributed to the repulsive electrostatic forces between the Lyz-MIP cryogel and lysozyme molecules.

Effects of ionic strength was also investigated by Gai et al., ref. [16], who have designed a bovine hemoglobin $(\mathrm{BHb})$-based molecularly imprinted gel polymers. Contrarily to Bereli et al., ref [15], their results indicate that hemoglobin adsorption is not dependent on $\mathrm{NaCl}$ concentration. The authors suppose that the electrostatic forces do not play, in this case, any role in the interaction between the investigated protein and the acrylamide monomers.

The effect of $\mathrm{pH}$ was investigated by Wang et al., who have synthetized tow MIPs for BSA [17] and $\mathrm{BHb}$ [18] detection. Results indicated that templates adsorption was maximum at $\mathrm{pH} 5.0$ and 7.0 for $\mathrm{BSA}$ and $\mathrm{BHb}$, respectively. This was attributed to the fact that these $\mathrm{pH}$ values were close to the isoelectric point (IP) of each protein. Saylan et al. [19] have studied the effect of $\mathrm{pH}$ on IgG adsorption in silica microsphere surface modified by aspartic acid MIP. They reported that the maximal adsorption of $\mathrm{IgG}$ is found at $\mathrm{pH}$, near to IgG IP (6.2). They attributed these finding to the electrostatic interaction between the positive charge of IgG and negative charge of aspartic acid (IP = 2.77). Nevertheless, it was reported in other studies $[20,21]$ that proteins were less soluble and less stable around their IP.

The inconsistency of these results raised the necessity to understand the effects of $\mathrm{pH}$ and ionic strength on the mechanisms of interaction between a considered protein and the imprinting sites. This is what we tried to do in this study. A polydopamine molecularly imprinted polymer was thus designed for BSA protein model detection. This choice was motivated by the fact that dopamine (DA) and BSA have comparable isoelectric points. In addition, $\mathrm{DA}$ is stable in different ionic strength and $\mathrm{pH}$ values and can be electropolymerized in physiologic environment [22]. The MIP design was inspired from the strategy of Tretjako et al. [23], which consists in creating well-ordered cavities. BSA templates were removed from the vicinity of the polymeric matrix by incubating the imprinted polymer in proteinase K solution. The corresponding nonmolecularly imprinted polymer, NIP, was prepared in the same conditions but without adding BSA templates.

Square wave voltammetry, zetametry, and Fourier-transform infrared spectrometry were investigated to control the surfaces' modification and to evaluate the effects of $\mathrm{pH}$ and the ionic strength on the interaction between a polydopamine molecular imprint and BSA protein model.

\section{Materials and Methods}

\subsection{Chemicals}

Sulfuric acid $\left(\mathrm{H}_{2} \mathrm{SO}_{4}, 95 \%\right)$, hydrogen peroxide $\left(\mathrm{H}_{2} \mathrm{O}_{2}, 30 \%\right)$, mercaptohexanol $(\mathrm{MHOH})$, acid mercaptoundecanoic (MUDA), bovine albumin serum (BSA), dopamine (DA), and proteinase K (pK) were purchased from Sigma Aldrich (Paris, France). N-hydroxysuccinimide (NHS), 1-ethyl-3-(3 dimethylaminopropyl)-carbodiimide hydrochloride (EDC), acetone, and ethanol were procured from Thermo Fisher (Artenay, France). A phosphate buffer solution (PBS) tablets were purchased from VWR (Strasbourg, France). Each tablet was dissolved in $100 \mathrm{~mL}$ of double ionized water (having a resistivity of $18.2 \mathrm{M} \Omega$ ). All the chemicals were of analytical grade and were used as received without further purification. 


\subsection{Instrumentation}

\subsubsection{Electrochemical Measurements}

Cyclic voltammetry (CV) and square wave voltammetry (SWV) were performed with a CHI 1222C. Gold, platinum, and $\mathrm{Ag} / \mathrm{AgCl}$ were used as the working, the auxiliary, and the reference electrodes, respectively. The following parameters were entered in all SWV measurements: increment $=4 \mathrm{mV}$, amplitude $=25 \mathrm{mV}$, frequency $=25 \mathrm{~Hz}$, quiet time $=2 \mathrm{~s}$, and sensitivity $=1 \times 10^{-3}$.

The work electrodes $\left(S=40 \mathrm{~mm}^{2}\right)$ were elaborated by the evaporation of $20 \mathrm{~nm} / 150 \mathrm{~nm}$ of chromium/gold thin layers on the surface of Kapton ${ }^{\circledR}$ polymers. Here, chromium was used as an intermediate layer to improve gold adhesion. All electrochemical results were expressed in terms of current density variation and calculated according to the equation:

$$
\mathrm{J}=\frac{\text { Current Intensity }}{\text { Electrodels surface }} .
$$

\subsubsection{Fourier-Transform Infrared Spectroscopy (FTIR)}

FTIR analyses were carried out with a Perkin Elmer "Spectrum two" spectrometer equipped with an attenuated total reflectance (ATR) cell. The spectra were collected at room temperature from 500 to $4000 \mathrm{~cm}^{-1}$ with a resolution of $2 \mathrm{~cm}^{-1}$. A background spectrum was recorded prior to each measurement and the further "background corrections" were systematically operated.

\subsubsection{Zetametry}

Zeta potentials measurements were performed with a Malvern Zetasizer Nano ZS. For each analysis, $0.1 \mathrm{~g}$ of BSA protein was dissolved in $1 \mathrm{~mL}$ of PBS, and zeta potential value was obtained by averaging three measurements.

\subsection{MIP Preparation}

Various cleaning steps were carried out on the gold surfaces prior to the MIP realization: the substrates were first immersed during $5 \mathrm{~min}$ in acetone and then for $5 \mathrm{~min}$ in ethanol under plannar agitation. The electrodes' surfaces were then activated with a piranha solution $\left(95 \% \mathrm{H}_{2} \mathrm{SO}_{4} / 30 \% \mathrm{H}_{2} \mathrm{O}_{2} 1: 1 \mathrm{v} / \mathrm{v}\right)$ during $10 \mathrm{~min}$ to favor the formation of $\mathrm{OH}$ groups on gold surfaces. This step was followed by a copious rinsing with ultrapure water and then with ethanol before drying under ambient air. After that, the substrates were incubated during $24 \mathrm{~h}$, at $4{ }^{\circ} \mathrm{C}$, in $3 \mathrm{~mL}$ of an ethanolic solution containing $0.1 \mathrm{M}$ MUDA and $1 \mathrm{mM} \mathrm{MHOH}$. A further ethanol rinsing $(5 \mathrm{~min})$ allowed the removal of the nonfixed molecules from the newly formed self-assembled monolayers (SAMs). A $50 \mu \mathrm{L}$ drop of EDC/NHS ( $75 \mathrm{mM} / 15 \mathrm{mM}$ ) solution was then deposited on the modified electrode, at ambient temperature and during $30 \mathrm{~min}$, to activate the - $\mathrm{COOH}$ groups. This step was followed by rinsing with ultrapure water prior to the deposition of a drop of $50 \mu \mathrm{L}$ of $0.1 \mathrm{mg} / \mathrm{mL}$ of BSA dissolved in PBS at $\mathrm{pH}$ 7.4. The modified surfaces were then washed with PBS solution to eliminate the non adsorbed proteins. The following step consists in electropolymerizing $20 \mathrm{mM}$ of dopamine, dissolved in $0.01 \mathrm{M}$ PBS, by voltammetry cyclic $(\mathrm{CV})$ at a potential ranging from -0.5 to $0.5 \mathrm{~V}$ and at a scanning speed of $50 \mathrm{mV} / \mathrm{s}$. The optimum thickness of the polydopamine (PDA) film was obtained after $17 \mathrm{CV}$ cycles (results not shown here). Further, $50 \mu \mathrm{L}$ of $20 \mathrm{mg} / \mathrm{mL}$ of proteinase $\mathrm{K}$ solution was then deposited on the substrates, during $2 \mathrm{~h}$ at $40{ }^{\circ} \mathrm{C}$ to remove the BSA templates. The electrodes were finally copiously rinsed with PBS, during $15 \mathrm{~min}$, and ultrapure water, during $15 \mathrm{~min}$, to eliminate any traces of nonadsorbed BSA molecules. A schema of the MIP's design strategy is presented in Figure 1a. 

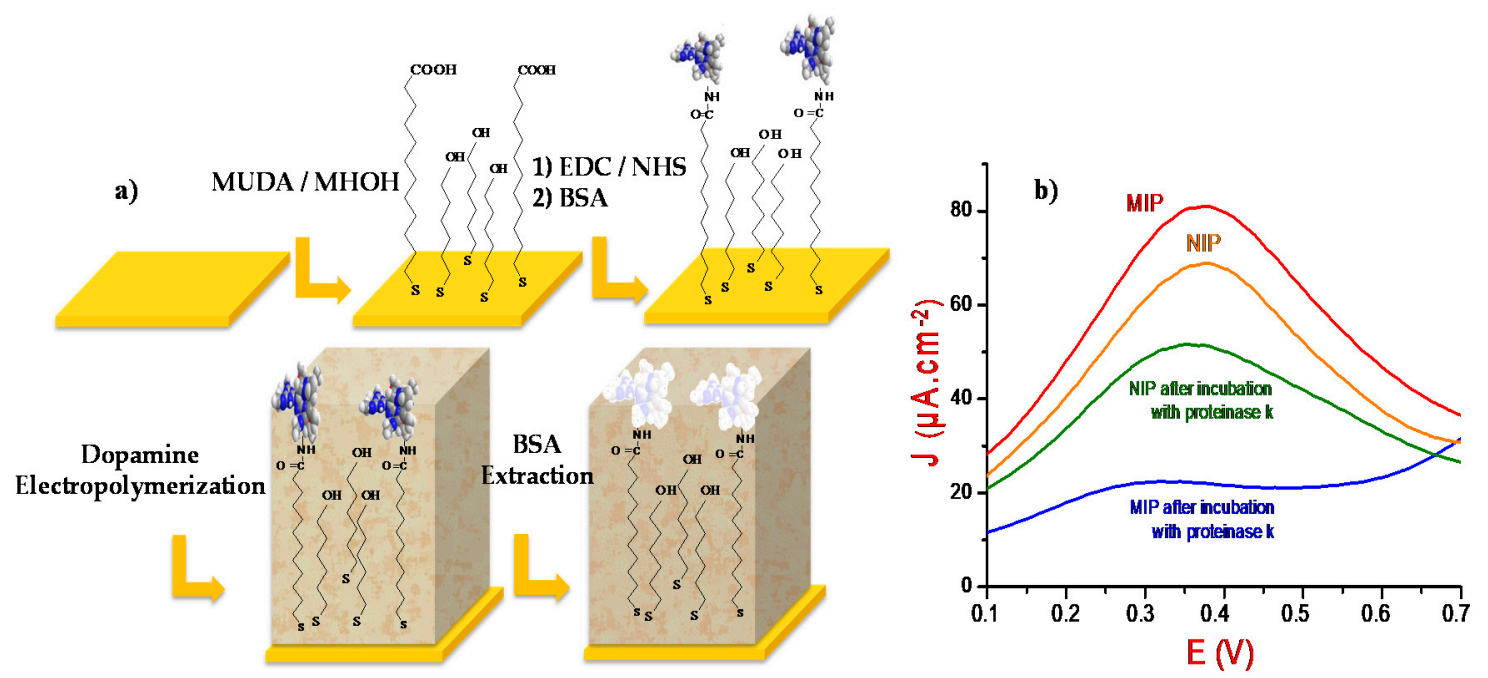

Figure 1. (a) Schematic representation of molecularly imprinted polymer (MIP) design strategy. (b) Square wave voltammograms of the MIP and the nonimprinted polymer (NIP) before and after incubation in proteinase K solution. Measurements were made in a $0.1 \mathrm{M}$ phosphate buffer solution (PBS) solution.

To control the affinity between the MIP and BSA protein, a nonimprinted polymer (NIP) was also designed in the same conditions as the MIP without adding BSA proteins, namely, MUDA/MHOH mixed SAMs were first grafted on the gold surfaces. MUDA's $\mathrm{COOH}$ groups were then activated by EDC/NHS prior to dopamine electropolymerization. The designed NIPs have thus the same chemical properties as the MIP ones, but do not contain specific cavities of BSA protein.

\section{Results and Discussion}

\subsection{MIP Design}

\subsubsection{MIP and NIP Electrochemical Characterization}

Square wave voltammetry was then conducted in PBS solutions, without adding redox probes, to control all the surface's modifications steps (Figure 1a). The MIP and NIP voltammograms, before and after incubation in proteinase $\mathrm{K}$ solution, are depicted in Figure $1 \mathrm{~b}$. Here, both BSA and polydopamine are electroactive in the investigated potential range. In fact, BSA protein is riche in electroactive amino-acid groups such as tryptophane, cysteine, and tyrosine [24], while polydopamine possesses a high functional activity and semiconducting properties [22]. The similarities between the functional groups in both polydopamine and BSA protein is probably at the origin of the generation of an electrochemical response, recorded in the same potential range. Besides, the square wave voltammograms presented in Figure 1b, highlight a significant current density decrease and a potential shift (from 0.371 to $0.315 \mathrm{~V}$ ) after BSA extraction. This indicates that the proteinase $\mathrm{K}$ has successfully removed the proteins from the vicinity of the polymeric matrix.

The percentage of extraction rate $(E R)$ was calculated from the equation:

$$
E R=\frac{J_{\text {MIP }}-J_{\text {extracted MIP }}}{J_{\text {MIP }}} \times 100,
$$

where $J_{\text {MIP }}$ and $J_{\text {extracted MIP }}$ are the current densities maxima of the MIP before and after the extraction step, respectively. ER was of order of $72 \%$.

The square wave voltammograms of the NIP before and after incubation in proteinase $\mathrm{K}$ solution are presented in Figure 1b. Compared to the MIP, the NIP presents a lower variation of current density. This can be attributed to the compact structure of the NIP which may hinder the electrons transfer toward the electrode surface. The current peak decrease after NIP dipping in proteinase K solution is probably due to the elimination of 
self-polymerized polydopamine fragments that were not directly and strongly grafted to the electrode surface [25].

\subsubsection{FTIR Characterization}

Fourier-transform infrared (FTIR) spectra of the MIP and the NIP are presented in Figure 2a. The similarity between these spectra is related to the fact that these polymers have the same backbone. For the large peak in the zone 1, ranging from 4000 to $3000 \mathrm{~cm}^{-1}$, we have chosen to operate a Gaussian deconvolution to better identify the functional groups present in the MIP and NIP structures (Figure 2b). The obtained bands at 3478 and $3303 \mathrm{~cm}^{-1}$ were assigned to the stretching vibrations of the amino $\mathrm{N}-\mathrm{H}$ and hydroxyl O-H groups, respectively [26].
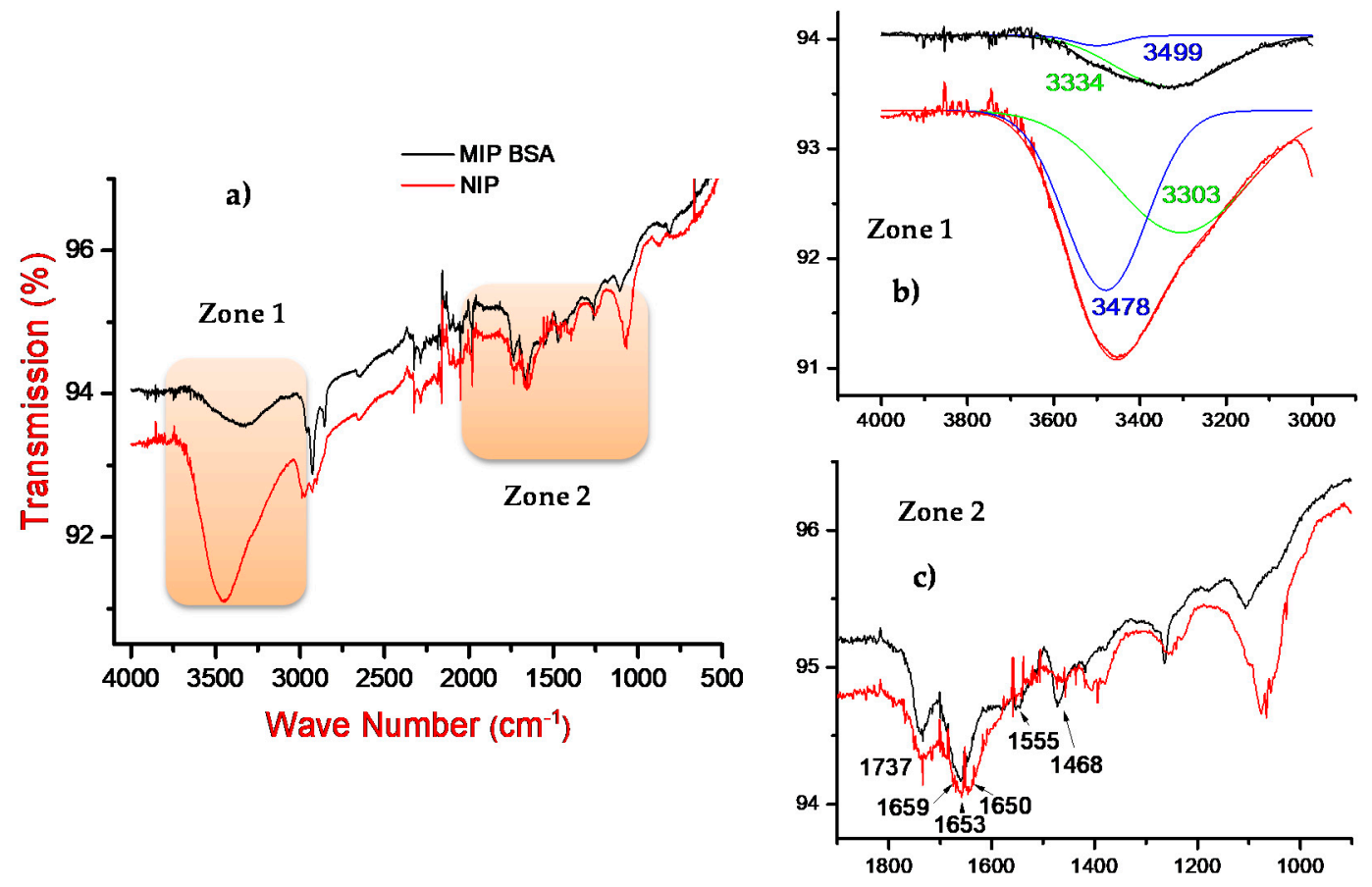

Figure 2. FTIR spectra of bovine serum albumin (BSA)/MIP and NIP at pH 7.4 (a) from 4000 to $500 \mathrm{~cm}^{-1}$. (b) A zoom on the zone 1 ranging from 4000 to $3000 \mathrm{~cm}^{-1}$ and the corresponding Gaussian deconvolution. (c) A zoom on the zone 2 ranging from 1900 to $800 \mathrm{~cm}^{-1}$.

A zoom on the zone 2, ranging from 1900 to $800 \mathrm{~cm}^{-1}$, is presented in Figure 2c. The bands at 1737 and $1659 \mathrm{~cm}^{-1}$, observed for both the MIP and NIP spectra, can be assigned to the elongation vibration of the $\mathrm{C}=\mathrm{O}$ group of the quinone, and the stretching vibration of the indole ring of polydopamine film, respectively [27]. Two specific bands are, however, present only for the MIP structure. The peaks at 1555 and $1468 \mathrm{~cm}^{-1}$, which can be attributed to the elongation vibration of the $\mathrm{N}-\mathrm{H}$ and asymmetric elongation of $\mathrm{C}-\mathrm{N}$ groups of secondary amide of BSA, respectively [28,29].

By comparing the FTIR spectra of MIP and NIP, we noticed that the MIP intensity is higher than the NIP one. This can be attributed to the creation of hydrogen bonds and electrostatic interactions $[30,31]$ between the BSA protein and the polydopamine matrix.

According to FTIR results and because of the importance of hydrogen bonds and electrostatic interactions on MIP-protein interaction, we have thus decided to conduct an exploratory study to elucidate the ionic strength and $\mathrm{pH}$ effects on the interaction mechanism between a given molecularly imprinted polymer (the PDA film in our case) and the BSA protein model. 
3.1.3. Electrochemical MIP Characterization at Different Ionic Strength and $\mathrm{pH}$ Values Ionic Strength Effects on MIP Elaboration

Studies, conducted to investigate the effect of high $\mathrm{NaCl}$ concentration on the MIPprotein interactions, have shown that this causes a decrease in proteins adsorption in their imprint's [15,19]. Literature has also reported that an increase in $\mathrm{NaCl}, \mathrm{KCl}, \mathrm{LiCl}$, or $\mathrm{CsCl}$ concentrations, induced denaturation and precipitation of proteins [32-34]. We have thus made the choice to use a phosphate buffer solution, which contains several ions $\mathrm{NaCl}, \mathrm{KCl}$, $\mathrm{Na}_{2} \mathrm{HPO}_{4}$ and $\mathrm{K}_{2} \mathrm{HPO}_{4}$ and adjusted its ionic strength to $16.7,42,167,250$, and $334 \mathrm{mM}$ at a fixed $\mathrm{pH}$ value of 7.4. This permits to investigate ionic strength effects in line of the buffering capacity of the considered solutions.

Square wave voltammetry was then investigated to follow-up the electrochemical responses of each designed MIP (results are not shown here). For each curve, we noted the maximum value of current density and, subsequently, plotted the variations of current densities versus ionic strength values on Figure 3.

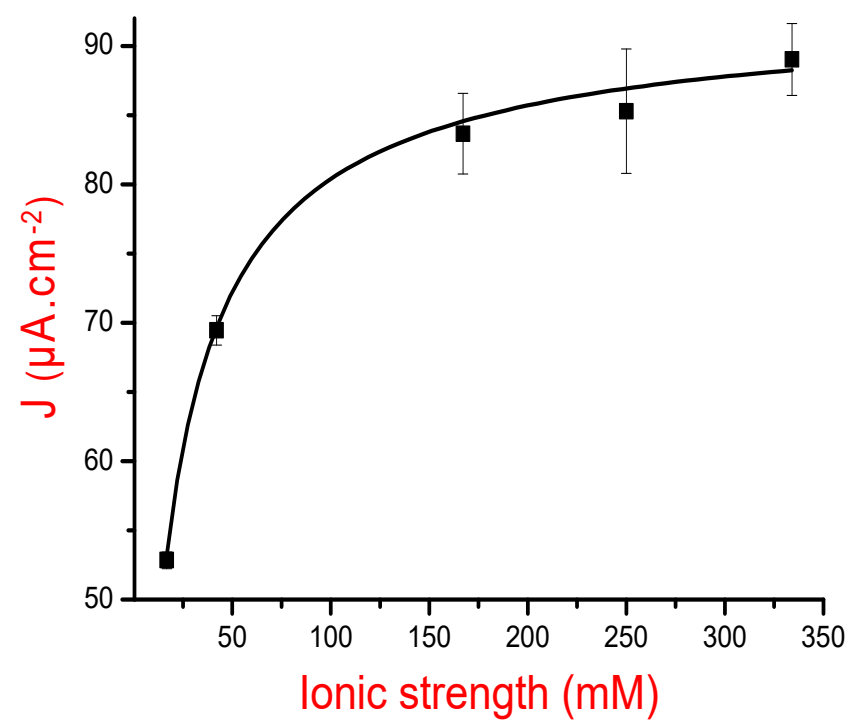

Figure 3. Variations of the current density maxima of MIPs designed at $\mathrm{pH}=7.4$ and varied ionic strengths versus the ionic strength of the BSA solution used in the MIPs' design.

Results presented in Figure 3 show that an increase in the ionic strength, during MIP construction, leads to current density augmentation and that the saturation is reached at $167 \mathrm{mM}$. This is attributed to the "salting-out effect" obtained at high salt concentrations leading to low protein stability [35].

\section{pH Effects on MIP Design}

$\mathrm{pH}$ can also be considered as a crucial key to the successful MIP-Protein design. ELSharif et al. have compared the recognition process between different proteins and their MIPs in various $\mathrm{pH}$ buffers [36]. They showed that depending on the isoelectric point of the investigated protein, the $\mathrm{pH}$ variations can influence templates/imprints specific binding. Based on the isoelectric point of the BSA (IP $=4.6)$, we selected, therefore, three $\mathrm{pH}$ values, i.e., 3.5, 7.4, and 9. During our investigations, we have varied the $\mathrm{pH}$ of the supporting electrolyte $\left(\mathrm{pH}_{\mathrm{PBS}}\right)$ and fixed the $\mathrm{pH}$ of the $\mathrm{BSA}$ templates $\left(\mathrm{pH}_{\mathrm{BSA}}\right)$, and then performed the inverse operation, i.e., fixing $\mathrm{pH}_{\mathrm{PBS}}$ and varying $\mathrm{pH}_{\mathrm{BSA}}$.

Here also, we have investigated square wave voltammetry to follow-up the electrochemical responses of each designed MIP, noted the maximum value of current density, and then plotted the variations of current densities versus $\mathrm{pH}$ values. For all these experiments, we have fixed both the ionic strength $(\mathrm{I}=167 \mathrm{mM})$ and the BSA concentration $\left(10^{-1} \mathrm{mg} / \mathrm{mL}\right)$. Results, presented in Figure $4 \mathrm{a}$, show that the MIP current density in- 
creases according to the $\mathrm{pH}$ of the supporting electrolyte and of BSA, except for the couple $\left(\mathrm{pH}_{\mathrm{BSA}}=9\right.$ and $\left.\mathrm{pH}_{\mathrm{PBS}}=9\right)$.
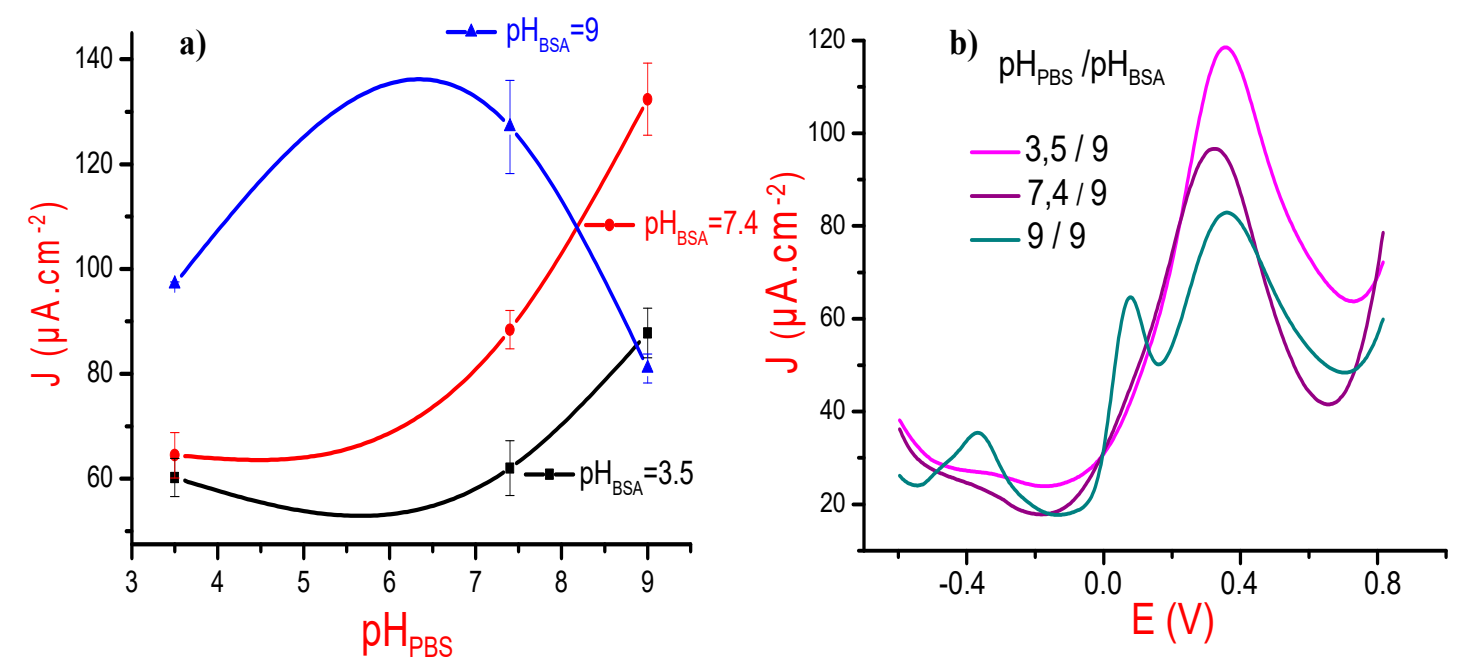

Figure 4. (a) Variations of the maxima of MIP current density versus the $\mathrm{pH}$ of the supporting electrolyte ( $\left.\mathrm{pH}_{\mathrm{PBS}}\right)$. $\mathrm{pH}$ values of BSA solutions used during the realization of the MIPs were equal to 3.5 (black curve), 7.4 (red curve), and 9.4 (blue curve). (b) Square wave voltammetry (SWV) voltammograms of MIPs designed with BSA protein solution at a fixed $\mathrm{pH}$ $\left(\mathrm{pH}_{\mathrm{BSA}}=9\right)$ and characterized at three different $\mathrm{pH}$ values of the $\mathrm{PBS}$ solution $\left(\mathrm{pH}_{\mathrm{PBS}}=3.5,7.4\right.$, and 9). All experiments were done at a fixed ionic strength $(\mathrm{I}=167 \mathrm{mM})$ and at BSA concentration equal to $10^{-1} \mathrm{mg} / \mathrm{mL}$.

Such finding could be explained by: (i) the polydopamine became more richer by negatively charged groups, such as the quinone-imine and catechol ones [37]. These chemical groups could in fact improve the polydopamine conductivity and electroactivity [22] and (ii) at $\mathrm{pH}$ values higher than BSA IP, the protein will have a net negative charge, leading to its electroactivity enhancement, which is confirmed by the potential zeta measurement (Table 1). Consequently, the amount of immobilized BSA can be expected to increase.

Table 1. Zeta potential values of bovine serum albumin (BSA) solutions for which the $\mathrm{pH}$ was adjusted at 3.5, 7.4, and 9. The BSA protein was dissolved at a fixed concentration of $10^{-1} \mathrm{mg} / \mathrm{mL}$.

\begin{tabular}{cc}
\hline $\mathrm{pH}_{\text {BSA }}$ & Zeta Potential $(\mathbf{m V})$ \\
\hline 3.5 & $5.77 \pm 1.00$ \\
7.4 & $-11.11 \pm 0.20$ \\
9 & $-10.66 \pm 0.05$ \\
\hline
\end{tabular}

To explain the particular shape of the curve corresponding to $\mathrm{pH}_{\mathrm{BSA}}=9$ in Figure $4 \mathrm{a}$, we have designed three MIPs with a fixed $\mathrm{pH}$ for the protein solution $\left(\mathrm{pH}_{\mathrm{BSA}}=9\right)$ and three different $\mathrm{pH}$ values for the PBS media: 3.5, 7.4, and 9. The corresponding square wave voltammograms, presented in Figure $4 \mathrm{~b}$, show three oxidation peaks, well separated and well resolved at only $\mathrm{pH}_{\mathrm{BSA}}=9$. These peaks can be attributed to the three amino acid residues of BSA: cysteine, tryptophan, and tyrosine [24,38]. Figure $4 \mathrm{~b}$ shows also that the current density of the MIP designed with $\left(\mathrm{pH}_{\mathrm{BSA}}=9\right.$ and $\left.\mathrm{pH}_{\mathrm{PBS}}=9\right)$ is inferior to the other ones, which may explain the particular variation in Figure $4 \mathrm{a}$.

These results stressed the fact that MIP elaboration is greatly dependent on the values of $\mathrm{pH}$ and ionic strength of both the templates and the supporting electrolyte, but what about the effects of these parameters on the analyte detection after the extraction procedure? 


\subsection{Effects of Ionic Strength and $p H$ on BSA Detection}

\subsubsection{Effects of Ionic Strength}

Five MIPs were first prepared at a fixed $\mathrm{pH}$ of 7.4 at different ionic strengths (16.7, $42,167,225$, and $334 \mathrm{mM}$ ), and then dipped in proteinase $\mathrm{K}$ solutions during $2 \mathrm{~h}$ to remove the BSA templates. After that, the designed MIPs were incubated in BSA solutions with concentrations increasing from $10^{-15}$ to $10^{-1} \mathrm{mg} / \mathrm{mL}$. Square wave electrochemical characterizations were then performed in PBS solutions prepared at the ionic strength of interest. For each measurement, we have noted the current density of BSA oxidation peak, and then plotted, for the whole measurements, the maximum of current densities versus BSA concentrations (Figure 5a). Results indicate that the maximum current density of BSA oxidation peak increases with ionic strength from 16.7 to $167 \mathrm{mM}$, and that beyond this value, an ionic strength increase leads to a current density decrease. These results can be explained by the fact that salt molecules can modify the MIP structure enhancing thus its volume, confirming thus the findings of Chen et al. in their study concerning lysozyme protein binding in a hydrogel layer [39]. Moreover, and according to Wang et al. [17,18], salt ions can also increase the proteins hydrability, which minimizes the protein affinity towards their polymeric cavities.
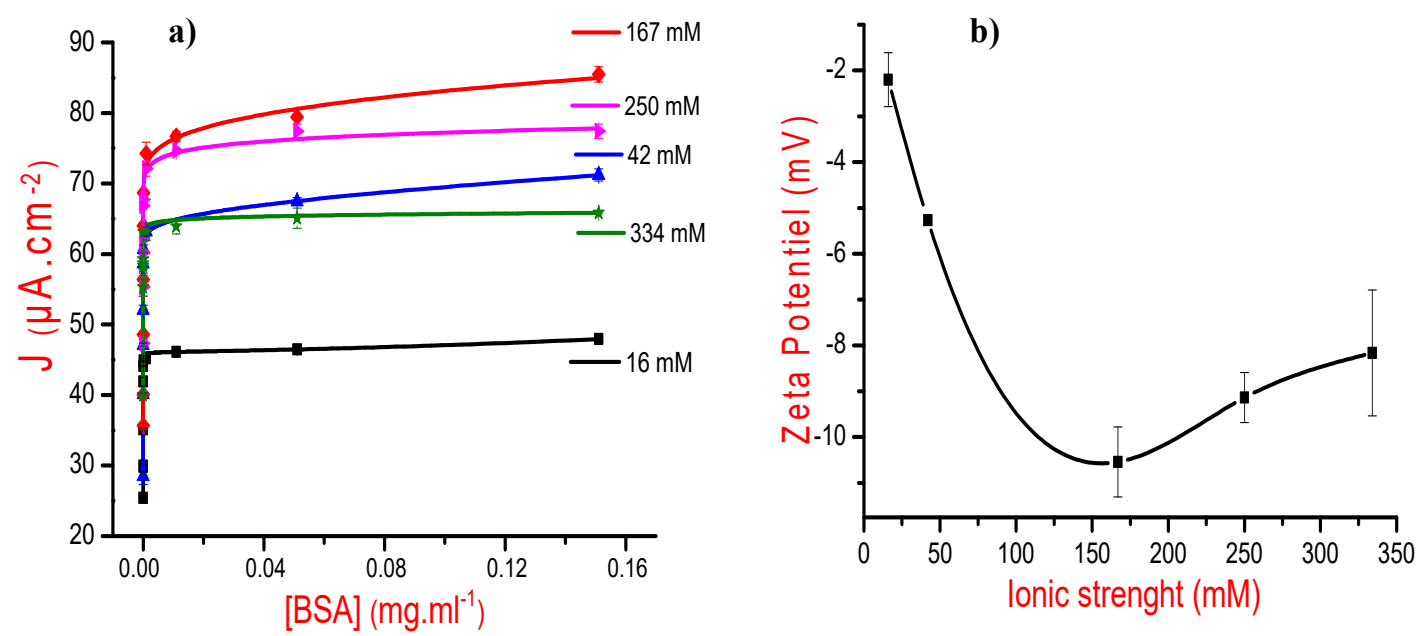

Figure 5. (a) Current density variations versus cumulative BSA concentrations for the four investigated ionic strengths: 16 , $7,42,167,250$, and $334 \mathrm{mM}$ (the lines are guides for the eyes). (b) Variation of the zeta potential versus the ionic strength (the lines are guides for the eye).

Zetametry technique was then performed to estimate zeta potential values of BSA protein under different salt concentrations (Figure 5b). Results indicate that, up to $167 \mathrm{mM}$, an ionic strength increase leads to a zeta potential decrease probably due to protein-protein repulsive interactions [40] and the good solubility and stability of BSA [41,42]. On the contrary, high ionic strengths provoke a slight augmentation of zeta potentials because of the consolidation of protein-protein interactions, thereby minimizing BSA solubility $[32,35]$. These results confirm that at high salt concentration, the hydrophobic regions of the protein react together and induce protein aggregation [35,43].

\subsubsection{Effects of $\mathrm{pH}$}

For a better understanding of the interaction between BSA and the polydopamine film, at different $\mathrm{pH}$ values (3.5, 7.4, and 9) and at a fixed ionic strength of $167 \mathrm{mM}$, we have compared the recognition of BSA analytes by both the imprinted and nonimprinted polymers. Here, we have made the choice to represent $\Delta J_{\text {MIP }}=J_{\text {MIP }}-J_{\text {MIP_ext }}$ and $\Delta J_{\text {NIP }}=J_{\text {NIP }}-J_{\text {NIP_ext }}$ versus cumulative BSA concentrations, where $J_{\text {MIP }}, J_{\text {NIP }}, \bar{J}_{\text {MIP_ext }}$, and $J_{\text {NIP_ext }}$ represent the recorded current densities of the MIP, the NIP, the extracted MIP, and the NIP dipped in the proteinase K extraction solution, respectively. Experiments were 
done three times for each couple of $\mathrm{pH}$ values ( $\mathrm{pH}_{\mathrm{BSA}}$ and $\mathrm{pH}_{\mathrm{PBS}}$ ), and we have considered the average curve as the calibration one. The obtained results are gathered on Figure 6.
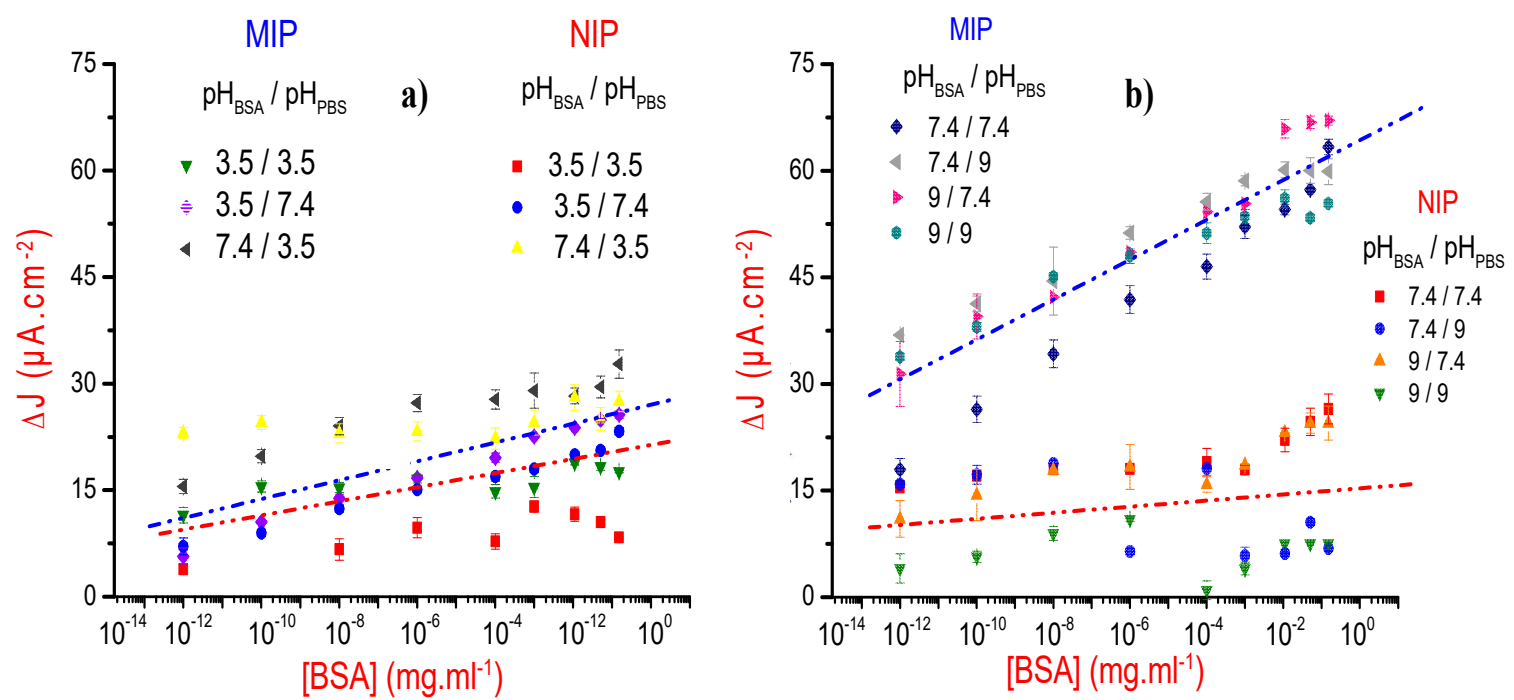

Figure 6. Variations of the current densities, $\Delta J_{\mathrm{MIP}}$ and $\Delta J_{\mathrm{NIP}}$ versus cumulative BSA concentration (in semilogarithmic representation): (a) For $\left(\mathrm{pH}_{\mathrm{BSA}}\right.$ or $\mathrm{pH}_{\mathrm{PBS}}$ ) lower than BSA isoelectric point (IP). (b) For ( $\mathrm{pH}_{\mathrm{BSA}}$ and $\mathrm{pH}_{\mathrm{PBS}}$ ) higher than BSA IP.

To highlight the $\mathrm{pH}$ effect and for a better visibility, we considered separately the cases where the $\mathrm{pH}_{\mathrm{BSA}}$ and/or $\mathrm{pH}_{\mathrm{PBS}}$ values are lower than the BSA isoelectric point (IP), of order of 4.6 according to our zetametry measurement (Figure 6a), and the cases where both $\mathrm{pH}$ values are higher than IP of BSA (Figure $6 \mathrm{~b}$ ).

Results presented in Figure 6a indicate that the MIP and NIP responses can be considered as similar for the first three $\mathrm{pH}$ pairs, given the measurement's dispersions and their associated uncertainties. This means that under these $\mathrm{pH}$ conditions, the adsorption phenomenon is relatively greater than the specific recognition of the analytes by the imprints. The rearrangement of surfacic charges and the variation of their density are probably at the origin of this unspecific recognition. Indeed, the polydopamine and the BSA are positively charged at $\mathrm{pH}$ lower than their isoelectric points, of order of 4 [44] and 4.6, respectively. This favors repulsive interaction and explains the fact that both NIP and MIP responses are the lowest ones when the $\mathrm{pH}$ values of BSA and PBS are equal to 3.5, and especially at higher concentrations of BSA.

When the $\mathrm{pH}$ values of BSA and PBS are higher than the isoelectric point of the BSA, the responses of the NIP and the MIP can be perfectly discriminated (Figure 6b), even when taking into account the results' dispersion and their uncertainties. This means that under these $\mathrm{pH}$ conditions, the BSA imprints play their expected recognition role.

Prior to the modelling of the electrochemical response of the MIP-based sensor, we have modelled the NIP-based one to remove the contribution of nonspecific adsorption response. Although it was not possible to obtain a unique model for all considered measurements, because of the great dispersion of results, we nevertheless noticed that a power law was suitable in the majority of the cases. This allows us to consider a combination of two models to fit the MIPs electrochemical responses: a "one site binding," for specific recognition, and a "power-law," for the nonspecific one (Equation (2)):

$$
\Delta J_{\mathrm{MIP}}(C)=\left(a+b \times C^{\alpha}\right)+\frac{m \times C}{K_{\mathrm{d}}+C^{\prime}}
$$

where $\Delta J_{\text {MIP }}(C)$ is the current density variation $\left(J_{\text {MIP }}(C)-J_{\text {MIP-ext }}(C)\right)$ for a given concentration $C$ of BSA, $K_{\mathrm{d}}$ is the dissociation constant, $a, b, m$, and the ponderation exponent $\alpha$ are empiric constants. 
In Figure 7 and its further inset are presented the calibration curves and their corresponding fits, in both linear and semilogarithmic scales. Sensitivities of the designed sensors were calculated from the semilogarithmic variations of the current densities, as they are quasilinear in a large concentration interval $\left[10^{-15}, 10^{-3}\right] \mathrm{mg} / \mathrm{mL}$. The calculated sensitivity and dissociation constants values are gathered in Table 2.

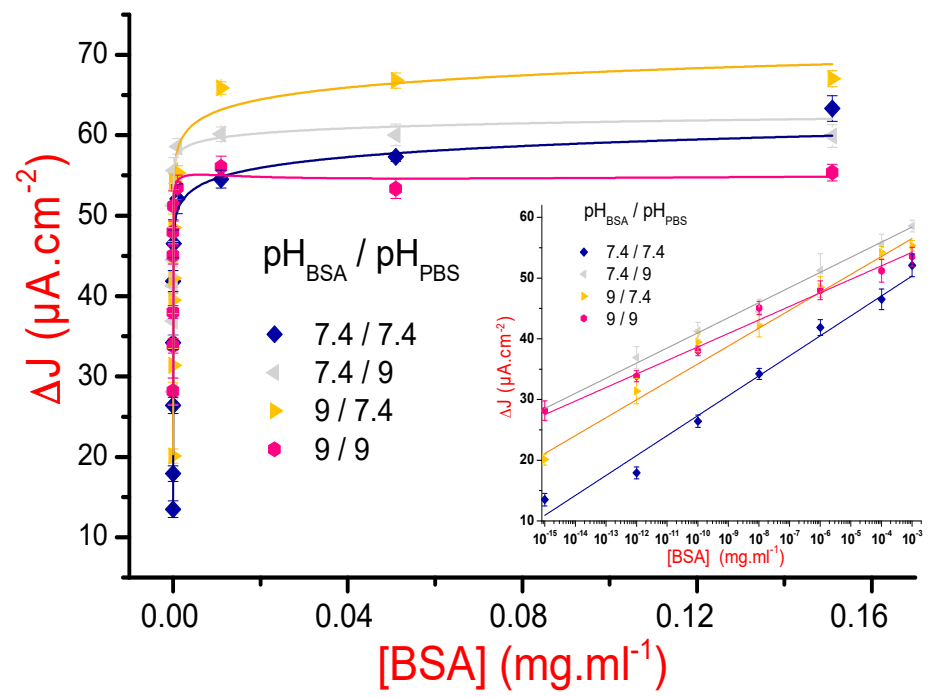

Figure 7. Variations of the current densities $\Delta J_{\text {MIP }}$ versus cumulative BSA concentration for $\mathrm{pH}_{\mathrm{BSA}}$ and $\mathrm{pH}_{\mathrm{PBS}}$ superior to the BSA isoelectric point. The solid lines correspond to the best fits according to Equation (2). Inset: semilogarithmic scale view showing the quasilinear shape of the calibration curves for BSA concentrations varying from $10^{-15}$ to $10^{-3} \mathrm{mg} / \mathrm{mL}$.

Table 2. Sensitivity and dissociation constants values.

\begin{tabular}{|c|c|c|c|}
\hline $\mathrm{pH}_{\mathrm{BSA}}$ & $\mathrm{pH}_{\mathrm{PBS}}$ & $\begin{array}{c}\text { Sensitivity } \\
\left(\mu \mathrm{A} \cdot \mathrm{cm}^{-2} \cdot \mathrm{mg}^{-1} \cdot \mathrm{mL}\right)\end{array}$ & $\begin{array}{c}\text { Dissociation Constant } \\
(\mathrm{mg} / \mathrm{mL})\end{array}$ \\
\hline 7.4 & 7.4 & $3.36 \pm 0.13$ & $(8.56 \pm 6.09) \times 10^{-11}$ \\
\hline 7.4 & 9 & $2.48 \pm 0.08$ & $(1.18 \pm 1.38) \times 10^{-6}$ \\
\hline 9 & 7.4 & $3.01 \pm 0.19$ & $(0.75 \pm 1.68) \times 10^{-6}$ \\
\hline 9 & 9 & $2.15 \pm 0.08$ & $(18.43 \pm 32.45) \times 10^{-3}$ \\
\hline
\end{tabular}

Table 2 data indicate that the best sensing condition, in terms of dissociation constant and sensitivity values, is that corresponding to $\left(\mathrm{pH}_{\mathrm{BSA}}=7.4\right.$ and $\left.\mathrm{pH} \mathrm{PBS}_{\mathrm{PBS}}=7.4\right)$. For the couples $\left(\mathrm{pH}_{\mathrm{BSA}}=7.4\right.$ and $\left.\mathrm{pH}_{\mathrm{PBS}}=9\right)$ and $\left(\mathrm{pH}_{\mathrm{BSA}}=9\right.$ and $\left.\mathrm{pH}_{\mathrm{PBS}}=7.4\right)$, the reading depends on whether the sensitivity or the dissociation constant is considered as the relevant parameter. Notice that the configuration in which both considered $\mathrm{pH}$ values are equal to 9 is the least favorable one and should not be considered in proteins detection. The high values of the dissociation constants uncertainties are mainly due to the large variability of nonspecific recognition, as we have showed in the experiments involving the nonimprinted polymer.

To better understand the interaction mechanism between BSA protein and its imprint in different $\mathrm{pH}$ media, acid, neutral, and basic, FTIR studies have been conducted and are presented in the next section.

\subsection{FTIR Analysis}

It is evident that the variation of $\mathrm{pH}$ plays a crucial role in the interaction mechanism between the polydopamine film and BSA protein. Three MIPs were thus designed and then characterized by FTIR spectroscopy. Herein, we have adjusted the $\mathrm{pH}$ of the supporting electrolyte ( $\left.\mathrm{pH}_{\mathrm{PBS}}\right)$ and the $\mathrm{pH}$ of the BSA solution $\left(\mathrm{pH}_{\mathrm{BSA}}\right)$ at $(3.5 / 3.5),(7.4 / 7.4)$, and (9/9). The corresponding spectra are presented in Figure 8. 


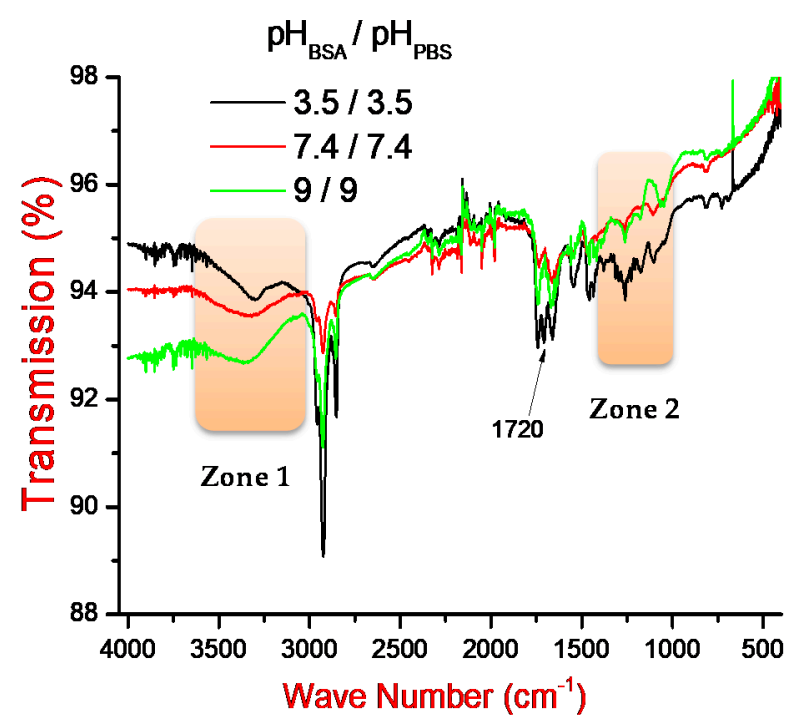

Figure 8. FTIR spectra of MIP response at $\mathrm{pH}_{\mathrm{BSA}} / \mathrm{pH}_{\mathrm{PBS}}$ adjusted to (3.5/3.5), (7.4/7.4) and (9/9).

Results show a variation in the band intensities at $\mathrm{pH} 3.5$ in the zone 1, ranging from 3500 to $3300 \mathrm{~cm}^{-1}$. This can be attributed to the asymmetric valence vibrations of the ammonium ion $\left(\mathrm{NH}_{3}^{+}\right)$formed during the $\left(\mathrm{R}^{-} \mathrm{NH}_{2}\right)$ protonation by the influence of the hydronium cation $\left(\mathrm{H}_{3} \mathrm{O}^{+}\right)$. At $\mathrm{pH} 7.4$ and 9, these bonds are large and present a higher absorption intensity, which is probably due to different intermolecular hydrogen bonds. The peaks recorded in the zone $2\left(1300-1200 \mathrm{~cm}^{-1}\right)$ and around $1720 \mathrm{~cm}^{-1}$, for the MIP designed at $\mathrm{pH} 3.5$, confirm the modification of the secondary structure of the protein, which leads to the appearance of the $\beta$-sheet conformation [45].

FTIR results indicate that the BSA is probably flattened at low $\mathrm{pH}$ values [46]. This may confirm our explanation in Section 3.2.1. We believe that the imprinted binding sites were not created at low $\mathrm{pH}$ values and that in this case, the interaction, between BSA and polymeric films, was only controlled by the electrostatic interaction.

\section{Conclusions}

We attempt in this work to understand the interaction mechanism between a protein model (BSA) and a polydopamine molecularly imprinted polymer. Three complementary techniques, electrochemistry, zetametry, and Fourier-transfer infrared spectroscopy, were used to understand the interaction between the PDA-MIP and BSA analytes and to investigate the roles of the ionic strength and the $\mathrm{pH}$ of both BSA and the buffer media. Results indicate that the best conditions, for a successful MIP-BSA design, were an ionic strength of $167 \mathrm{mM}$ and a $\mathrm{pH}$ value of 7.4, two conditions that ensure a good structural stability of the protein and high electroactivity of the polydopamine polymeric matrix. The corresponding electrochemical sensor has a sensitivity of $(3.36 \pm 0.13) \mu \mathrm{A} \cdot \mathrm{cm}^{-2} \cdot \mathrm{mg}^{-1} \cdot \mathrm{mL}$ and a dissociation constant $\mathrm{K}_{\mathrm{d}}$ of order of $(8.56 \pm 6.09) \times 10^{-11} \mathrm{mg} / \mathrm{mL}$, which indicates a high affinity between the BSA protein and the polydopamine molecular imprint.

The final objective of this exploratory study is to draw attention on the fact that beyond the choice of the chemical structure of the functional monomers, the cross-linker agent and the polymerization technique, three other parameters are crucial in the design of a molecularly imprinted polymer that are the ionic strength, $\mathrm{pH}$, and the isoelectric point. These parameters are of prime importance in the case of MIP designed for protein detection, as each protein in cells has different folding mechanisms and 3D structures in various $\mathrm{pH}$ and ionic strength conditions.

Author Contributions: A.T. has performed the electrochemical and zeta potential measurements; A.T. and S.K. have performed the FTIR characterization; N.Y. realized the Kapton electrode; C.Z. and G.A. analyzed the data experiments; A.O. and N.F. conceived, designed and supervised the 
experiments. A.T., A.O., C.Z., G.A., N.F., Z.M. and S.K. have participate in the manuscript writing. All authors have read and agreed to the published version of the manuscript.

Funding: Campus France and CMCU committee via the PHC Utique project no 34884 QF/16G 0808 TU.

Institutional Review Board Statement: Not applicable.

Informed Consent Statement: Not applicable.

Data Availability Statement: Not applicable.

Acknowledgments: The authors would like to thank Campus France and CMCU committee for the financial support of this work via the PHC Utique project no 34884 QF/16G 0808 TU. A.T. and N.F. would like to thank Catherine Gomez (Laboratoire de Génomique, bioinformatique et chimie moléculair, Cnam, Paris) for the provision of the zetameter and her help in setting up of the corresponding experiments.

Conflicts of Interest: The authors declare no conflict of interest.

\section{References}

1. Yi, L.X.; Fang, R.; Chen, G.H. Molecularly imprinted solid-phase extraction in the analysis of agrochemicals. J. Chromatogr. Sci. 2013, 51, 608-618. [CrossRef] [PubMed]

2. Wei, W.; Zhou, T.; Wu, S.; Shen, X.; Zhu, M.; Li, S. An enzyme-like imprinted-polymer reactor with segregated quantum confinements for a tandem catalyst. RSC Adv. 2018, 8, 1610-1620. [CrossRef]

3. Yang, S.; Wang, Y.; Jiang, Y.; Li, S.; Liu, W. Molecularly imprinted polymers for the identification and separation of chiral drugs and biomolecules. Polymers 2016, 8, 216. [CrossRef] [PubMed]

4. Chen, L.; Wang, X.; Lu, W.; Wu, X.; Li, J. Molecular imprinting: Perspectives and applications. Chem. Soc. Rev. 2016, 45, $2137-2211$. [CrossRef] [PubMed]

5. Ansari, S.; Masoum, S. Trends in Analytical Chemistry Molecularly imprinted polymers for capturing and sensing proteins: Current progress and future implications. Trends Anal. Chem. 2019, 114, 29-47. [CrossRef]

6. Regan, B.; Boyle, F.; O'Kennedy, R.; Collins, D. Evaluation of molecularly imprinted polymers for point-of-care testing for cardiovascular disease. Sensors 2019, 19, 3485. [CrossRef]

7. Refaat, D.; Aggour, M.G.; Farghali, A.A.; Mahajan, R.; Wiklander, J.G.; Nicholls, I.A.; Piletsky, S.A. Strategies for molecular imprinting and the evolution of MIP nanoparticles as plastic antibodies—Synthesis and applications. Int. J. Mol. Sci. 2019, 20, 6304. [CrossRef]

8. Crapnell, R.D.; Hudson, A.; Foster, C.W.; Eersels, K.; Grinsven, B.V.; Cleij, T.J.; Peeters, M. Recent advances in electrosynthesized molecularly imprinted polymer sensing platforms for bioanalyte detection. Sensors 2019, 19, 1204. [CrossRef]

9. Cai, D.; Ren, L.; Zhao, H.; Xu, C.; Zhang, L.; Yu, Y.; Wang, H.; Lan, Y.; Roberts, M.F.; Chuang, J.H.; et al. A molecular-imprint nanosensor for ultrasensitive detection of proteins. Nat. Nanotechnol. 2010, 5, 597-601. [CrossRef]

10. Graham, S.P.; El-Sharif, H.F.; Hussain, S.; Fruengel, R.; McLean, R.K.; Hawes, P.C.; Sullivan, M.V.; Reddy, S.M. Evaluation of Molecularly Imprinted Polymers as Synthetic Virus Neutralizing Antibody Mimics. Front. Bioeng. Biotechnol. 2019, 7, 1-7. [CrossRef]

11. Yang, X.; Dong, X.; Zhang, K.; Yang, F.; Guo, Z. A molecularly imprinted polymer as an antibody mimic with affinity for lysine acetylated peptides. J. Mater. Chem. B 2016, 4, 920-928. [CrossRef] [PubMed]

12. Stojanovic, Z.; Erdőssy, J.; Keltai, K.; Scheller, F.W.; Gyurcsányi, R.E. Electrosynthesized molecularly imprinted polyscopoletin nanofilms for human serum albumin detection. Anal. Chim. Acta 2017, 977, 1-9. [CrossRef] [PubMed]

13. Kryscio, D.R.; Peppas, N.A. Acta Biomaterialia Critical review and perspective of macromolecularly imprinted polymers. Acta Biomater. 2012, 8, 461-473. [CrossRef] [PubMed]

14. Ge, Y.; Turner, A.P. Too large to fit? Recent developments in macromolecular imprinting. Trends Biotechnol. 2008, 26, 218-224. [CrossRef]

15. Bereli, N.; Andaç, M.; Baydemir, G.; Say, R.; Galaev, I.Y.; Denizli, A. Protein recognition via ion-coordinated molecularly imprinted supermacroporous cryogels. J. Chromatogr. A 2008, 1190, 18-26. [CrossRef]

16. Gai, Q.; Qu, F.; Zhang, Y. The preparation of BHb-molecularly imprinted gel polymers and its selectivity comparison to BHb and BSA. Sep. Sci. Technol. 2010, 45, 2394-2399. [CrossRef]

17. Wang, Y.; Wei, T.X. Surface plasmon resonance sensor chips for the recognition of bovine serum albumin via electropolymerized molecularly imprinted polymers. Chin. Chem. Lett. 2013, 24, 813-816. [CrossRef]

18. Wang, Y.; Zhang, Q.; Ren, Y.; Jing, L.; Wei, T. Molecularly imprinted polymer thin film based surface plasmon resonance sensor to detect hemoglobin. Chem. Res. Chin. Univ. 2014, 30, 42-48. [CrossRef]

19. Saylan, Y.; Üzek, R.; Uzun, L.; Denizli, A. Surface imprinting approach for preparing specific adsorbent for IgG separation. J. Biomater. Sci. Polym. Ed. 2014, 25, 881-894. [CrossRef] 
20. Nadendla, K.; Friedman, S.H. Light Control of Protein Solubility through Isoelectric Point Modulation. J. Am. Chem. Soc. 2017, 139, 17861-17869. [CrossRef]

21. Gehring, C.; Davenport, M.; Jaczynski, J. Functional and Nutritional Quality of Protein and Lipid Recovered from Fish Processing by-Products and Underutilized Aquatic Species Using Isoelectric Solubilization/Precipitation. Curr. Nutr. Food Sci. 2009, 5, 17-39. [CrossRef]

22. Coskun, H.; Aljabour, A.; Uiberlacker, L.; Strobel, M.; Hild, S.; Cobet, C.; Farka, D.; Stadler, P.; Sariciftci, N.S. Chemical vapor deposition-based synthesis of conductive polydopamine thin-films. Thin Solid Films 2018, 645, 320-325. [CrossRef]

23. Tretjakov, A.; Syritski, V.; Reut, J.; Boroznjak, R.; Volobujeva, O.; Öpik, A. Surface molecularly imprinted polydopamine films for recognition of immunoglobulin G. Microchim. Acta 2013, 180, 1433-1442. [CrossRef]

24. Chiku, M.; Ivandini, T.A.; Kamiya, A.; Fujishima, A.; Einaga, Y. Direct electrochemical oxidation of proteins at conductive diamond electrodes. J. Electroanal. Chem. 2008, 612, 201-207. [CrossRef]

25. Jolly, P.; Tamboli, V.; Harniman, R.; Estrela, P.; Allender, C.J.; Bowen, J.L. Aptamer-MIP hybrid receptor for highly sensitive electrochemical detection of prostate specific antigen. Biosens. Bioelectron. 2016, 75, 188-195. [CrossRef]

26. Alhazmi, H.A. FT-IR spectroscopy for the identification of binding sites and measurements of the binding interactions of important metal ions with bovine serum albumin. Sci. Pharm. 2019, 87, 5. [CrossRef]

27. Weng, S.; Liang, D.; Qiu, H.; Liu, Z.; Lin, Z.; Zheng, Z.; Liu, A.; Chen, W.; Lin, X. A unique turn-off fluorescent strategy for sensing dopamine based on formed polydopamine (pDA) using graphene quantum dots (GQDs) as fluorescent probe. Sens. Actuators $B$ Chem. 2015, 221, 7-14. [CrossRef]

28. Barth, A. Infrared spectroscopy of proteins. Biochim. Biophys. Acta Bioenerg. 2007, 1767, 1073-1101. [CrossRef]

29. Kuzmenko, D.; Arkhangelsky, E.; Belfer, S.; Freger, V.; Gitis, V. Chemical cleaning of UF membranes fouled by BSA. Desalination 2005, 179, 323-333. [CrossRef]

30. Zakaria, N.D.; Yusof, N.A.; Haron, J.; Abdullah, A.H. Synthesis and evaluation of a molecularly imprinted polymer for 2,4Dinitrophenol. Int. J. Mol. Sci. 2009, 10, 354-365. [CrossRef]

31. Nurhayati, T.; Royani, I. Synthesis and characterization of MAA-based molecularly-imprinted polymer (MIP) with D-glucose template. J. Phys. Conf. Ser. 2016, 739, 012134.

32. Parsons, D.F.; Boström, M.; Nostro, P.L.; Ninham, B.W. Hofmeister effects: Interplay of hydration, nonelectrostatic potentials, and ion size. Phys. Chem. Chem. Phys. 2011, 13, 12352-12367. [CrossRef] [PubMed]

33. Curtis, R.A.; Lue, L. A molecular approach to bioseparations: Protein-protein and protein-salt interactions. Chem. Eng. Sci. 2006, 61, 907-923. [CrossRef]

34. Moghaddam, S.Z.; Thormann, E. The Hofmeister series: Specific ion effects in aqueous polymer solutions. J. Colloid Interface Sci. 2019, 555, 615-635. [CrossRef] [PubMed]

35. Gerzhova, A.; Mondor, M.; Benali, M.; Aider, M. Study of total dry matter and protein extraction from canola meal as affected by the $\mathrm{pH}$, salt addition and use of zeta-potential/turbidimetry analysis to optimize the extraction conditions. Food Chem. 2016, 201, 243-252. [CrossRef]

36. EL-Sharif, H.F.; Phan, Q.T.; Reddy, S.M. Enhanced selectivity of hydrogel-based molecularly imprinted polymers (HydroMIPs) following buffer conditioning. Anal. Chim. Acta 2014, 809, 155-161. [CrossRef]

37. Dreyer, D.R.; Miller, D.J.; Freeman, B.D.; Paul, D.R.; Bielawski, C.W. Elucidating the structure of poly(dopamine). Langmuir 2012, 28, 6428-6435. [CrossRef]

38. Pandey, P.; Pandey, A.; Shukla, N.K. Screen Printed Gold Electrode with Cysteamine and Single Walled Carbon Nanotubes for the Recognition of Prostate Specific Antigen. Mater. Today Proc. 2018, 5, 15311-15318. [CrossRef]

39. Chen, Z.; Hua, Z.; Xu, L.; Huang, Y.; Zhao, M. Protein-responsive imprinted polymers with specific shrinking and rebinding y. Interdiscip. J. 2008, 21, 71-77. [CrossRef]

40. Zhang, J. Protein-Protein Interactions in Salt Solutions. Protein Protein Interact Comput. Exp. Tools 2012. [CrossRef]

41. Formaneck, M.S.; Ma, L.; Cui, Q. Effects of temperature and salt concentration on the structural stability of human lymphotactin: Insights from molecular simulations. J. Am. Chem. Soc. 2006, 128, 9506-9517. [CrossRef] [PubMed]

42. Hergli, E.; Aschi, A. Polycation-globular protein complex: Ionic strength and chain length effects on the structure and properties. E-Polymers 2019, 19, 120-128. [CrossRef]

43. Patel, R.; Kumari, M.; Khan, A.B. Recent advances in the applications of ionic liquids in protein stability and activity: A review. Appl. Biochem. Biotechnol. 2014, 172, 3701-3720. [CrossRef] [PubMed]

44. Klosterman, L.; Bettinger, C.J. Calcium-mediated control of polydopamine film oxidation and iron chelation. Int. J. Mol. Sci. 2017, 18, 14. [CrossRef] [PubMed]

45. Navarra, G.; Peres, C.; Contardi, M.; Picone, P.; Biagio, P.L.S.; Di Carlo, M.; Giacomazza, D.; Militello, V. Heat- and pH-induced BSA conformational changes, hydrogel formation and application as 3D cell scaffold. Arch Biochem. Biophys. 2016, 606, 134-142. [CrossRef]

46. Varga, N.; Hornok, V.; Sebok, D.; Dékány, I. Comprehensive study on the structure of the BSA from extended-to aged form in wide (2-12) pH range. Int. J. Biol. Macromol. 2016, 88, 51-58. [CrossRef] 